SAINS TANAH - Journal of Soil Science and Agroclimatology

Journal homepage: http://jurnal.uns.ac.id/tanah

\title{
Silicon (Si) and salinity stress on the agronomic performances of bok choy (Brassica rappa L.) in an Entisols
}

\author{
Kharisun $^{1 *}$, Mochamad Nazarudin Budiono ${ }^{1}$, Nur Prihatiningsih ${ }^{1}$, Ratri Noorhidayah ${ }^{1}$, Ningsih Lamorunga ${ }^{2}$ \\ ${ }^{1}$ Faculty of Agriculture, Universitas Jenderal Soedirman, Purwokerto, Indonesia \\ ${ }^{2}$ Undergraduate of Agrotechnology Study Program, Faculty of Agriculture, Universitas Jenderal Soedirman, Purwokerto, Indonesia
}

\begin{tabular}{|c|c|}
\hline ARTICLE INFO & ABSTRACT \\
\hline $\begin{array}{l}\text { Keywords: } \\
\text { Bok choy } \\
\text { Silicon fertilizer } \\
\text { Salt stress } \\
\text { Entisols } \\
\text { Article history } \\
\text { Submitted: 2019-12-19 } \\
\text { Accepted: 2020-12-02 } \\
\text { Available online: 2020-12-30 } \\
\text { * Corresponding Authors } \\
\text { Email address: } \\
\text { h_kharisun@yahoo.com }\end{array}$ & 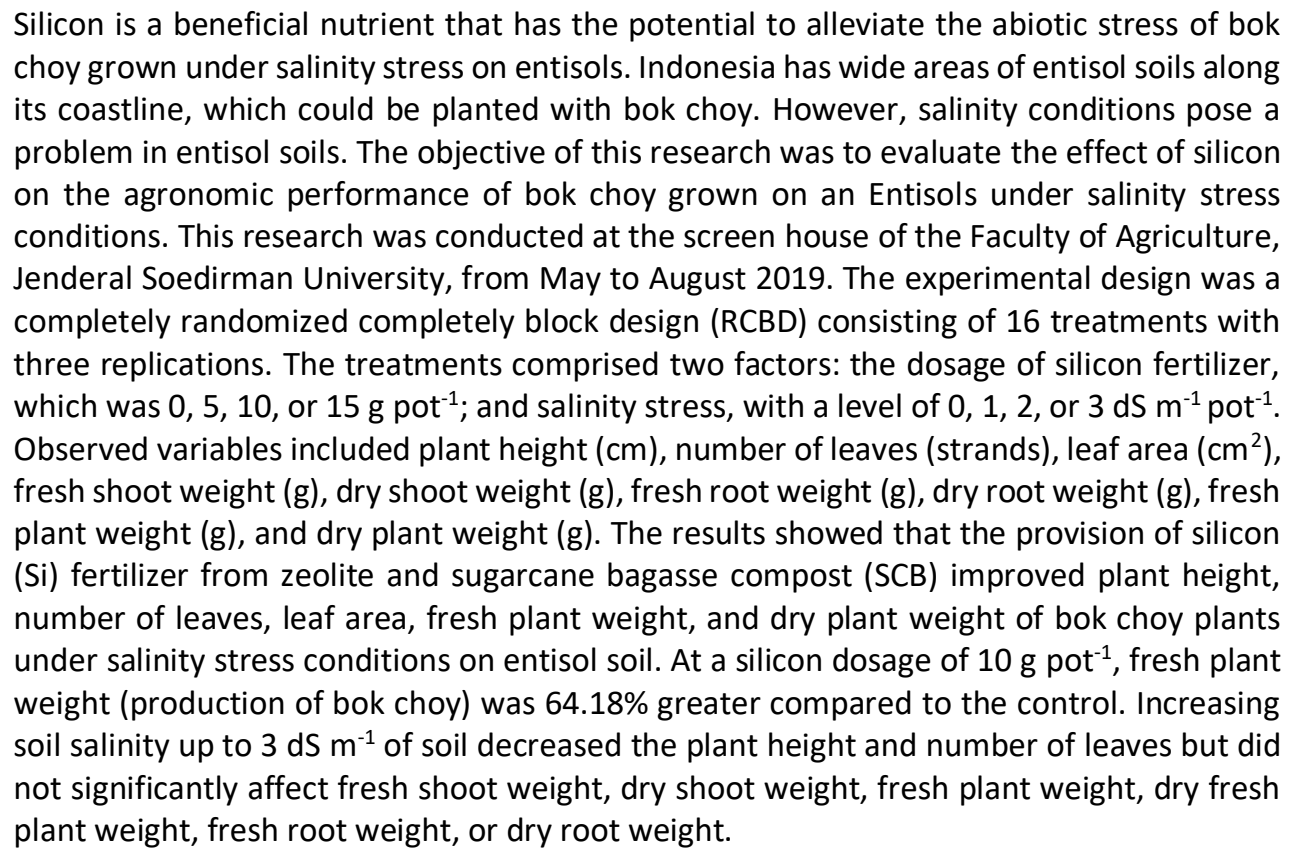 \\
\hline
\end{tabular}

How to Cite: Kharisun, Budiono, M. N., Prihatiningsih, N., Noorhidayah, R., and Lamorunga, N. (2020). Silicon (Si) and salinity stress on the agronomic performances of bok choy (Brassica rappa L.) in an Entisols. Sains Tanah Journal of Soil Science and Agroclimatology, 17(2): 108-114 (doi: 10.20961/stjssa.v17i2.37827)

\section{Introduction}

Bok choy is a popular vegetable in Indonesia, in very high demand for household needs and the food industry. However, despite the increasing demand for bok choy, the production of bok choy has recently decreased and is unable to fulfill the market demand (Husnaeni \& Setiawati, 2018). One opportunity to increase bok choy production is the use of entisols as planting areas (Usfiani et al., 2016). This soil is spread along the vast coastal land area of Indonesia and has not been utilized optimally. The total length of Indonesia's coastline is 99,093 km (Auliani, 2013). However, these soils tend to have several complications, including a high salt content (salinity condition), low contents of clay particles, and a lack of organic matter (Sipayung, 2003). The salinity problem is commonly more severe during the dry season due to the interference of seawater in the soil.

The negative effects of salinity on plants, such as retarded growth, fruit defects, amount of chlorophyll, and potassium contents induce hyperosmotic stress and ion imbalance, decreasing membrane integrity and protein synthesis (Deinlein et al., 2014; Liu et al., 2019; Mindari, 2009; Shahzad et al., 2012; Zare et al., 2015). Some mechanisms by which salinity decreases the performance of plant growth have been explored, including low external water potential, ion toxicity, and interference with the uptake of nutrients (Azizi et al., 2016). Salinity leads to plant death by ionic and osmotic stress, which causes nutrient imbalance, membrane damage, and enzymatic inhibition (Hasanuzzaman et al., 2013). The negative effects of salinity stress can be corrected with the 
application of proper fertilizers and soil amendments (Makoi \& Verplancke, 2010). Silicon is deemed to be a potential nutrient to improve the agronomic performance of the plant and alleviate abiotic stresses such as the salinity problem in coastal Entisols (Ahmed et al., 2011; Hanafy Ahmed et al., 2008; Nascimento et al., 2018; Sabaghnia \& Janmohammadi, 2015; Zare et al., 2015). Some other studies showed that Silicon also reduces the uptake of sodium by plants (Farooq et al., 2019; Ning et al., 2014) and increases the content of polyamines under salt stress (Yin et al., 2016), uptake of $\mathrm{K}$ (Ghassemi-Golezani \& Lotfi, 2015; Soundararajan et al., 2017; Tantawy et al., 2015), increased resistance to essential nutrient deficiencies, and enhanced photosynthesis of plants (Ma \& Takahashi, 2002). Azizi et al. (2016) stated that silicon nutrition could allow recovery of the chlorophyll content and the number of soluble proteins in Medicago scutellata plants under salinity stress. Therefore, silicon has the potential to alleviate the problem of salinity stress in plants. Most research on the application of $\mathrm{Si}$ to improve growth and production has used synthetic inorganic material. Some materials commonly used as sources of silicon fertilization to plants are calcium and magnesium silicate (Camargo et al., 2013), sodium silicate (Azizi et al., 2016), silicon dioxide $\left(\mathrm{SiO}_{2}\right)$ with $95 \%$ silicon (Oliveira et al., 2016), and other inorganic materials. In this research, natural materials such as zeolite and sugarcane bagasse compost ( SCB) were used as sources of silicon because they are abundant in Indonesia (Yustinah, 2013) and are capable of improving the productivity of entisol soil. Zeolite and SCB have a high cation exchange capacity and high water absorption capacity, which can counteract the main weaknesses of the entisol soil (Kertonegoro, 2001).

Furthermore, no research has previously been conducted on the potential of silicon to alleviate salinity stress in bok choy, except for some research on other horticultural crops such as cucumbers, capsicums, strawberries, melons, and roses under several abiotic stresses including salinity stress. The objectives of this research are to evaluate the effects of silicon from zeolite and SCB in improving the growth performance of bok choy grown in Entisols under salinity stress conditions.

\section{Materials and Method}

The research consisted of a pot experiment conducted at the screen house of the Faculty of Agriculture, Jenderal Soedirman University from May to August 2019. The experimental design used was a factorial randomized block design (RBD) consisting of 16 treatments with 3 replications as blocks. The treatments consisted of two factors; the first factor was salinity stress, tested at 4 levels (control $\left(K_{0}\right), 1 \mathrm{dS}$ $\mathrm{m}^{-1}\left(\mathrm{~K}_{1}\right), 2 \mathrm{dS} \mathrm{m} \mathrm{m}^{-1}\left(\mathrm{~K}_{2}\right)$, and $\left.3 \mathrm{dS} \mathrm{m} \mathrm{m}^{-1}\left(\mathrm{~K}_{3}\right)\right)$. The second factor was the dosage of silicon fertilizer $\left(0 \mathrm{~g} \mathrm{Si} \mathrm{pot}^{-1}\left(\mathrm{~S}_{0}\right), 5 \mathrm{~g}\right.$ Si pot ${ }^{1}\left(\mathrm{~S}_{1}\right), 10 \mathrm{~g} \mathrm{Si} \mathrm{pot}^{-1}\left(\mathrm{~S}_{2}\right)$, and $\left.15 \mathrm{~g} \mathrm{Si} \mathrm{pot}^{-1}\left(\mathrm{~S}_{3}\right)\right)$. The salinity of the soil was measured and additional $\mathrm{KCl}$ was provided to achieve each desired level of salinity stress treatment. The control condition was the original salinity of the soil. The salinity stressor was applied 1 day before planting.

The materials used for the silicon sources are SCB and zeolite, with $20 \%$ of silicon coming from SCB and $80 \%$ from the zeolite. The silicon was prepared by composting the SCB and crushing the zeolite to a 200 mesh size fraction. SCB was composted for 3 months in a $25 \mathrm{~kg}$ drum composter with decomposing bacteria and molasses added. The result of composting showed that SCB had a $\mathrm{SiO}_{2}$ content of $5.82 \%$. The preparation of silicon from zeolite was conducted by crushing and grinding zeolite to pass through a 200 mesh size sieve. The zeolite was then thermally activated at $105^{\circ} \mathrm{C}$ in an oven for 24 hours. The activated zeolite $\mathrm{SiO}_{2}$ content was $52.34 \%$. The contents of silicon in the SCB and activated zeolite were then used to obtain the desired proportions of silicon in each level of treatment, i.e., $0 \mathrm{~g} \mathrm{Si}(0 \mathrm{~g} \mathrm{SCB}$ and $0 \mathrm{~g}$

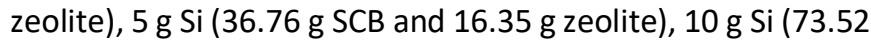
g SCB and 32.70 g zeolite), $15 \mathrm{~g}$ Si (110.29 g SCB and $49.05 \mathrm{~g}$ zeolite). The material for salinity treatment was $\mathrm{KCl}$, which was applied to the soil in amounts calculated based on the electrical conductivity of the original soil as the control (Ayers \& Westcot, 1985).

The planting media used were Entisols collected from the coastal area of Jetis, Cilacap Regency (Table 1). The soil samples were dried, crushed, and passed through a $5.0 \mathrm{~mm}$ sieve to obtain a more homogenous soil. Prior to the measurement of the water content, the soil samples were airdried for about 2 weeks. The water content at the field collection site was also determined. The results of the analysis of some selected characteristics of the soil are presented in Table 1. The air-dried soil was then weighed and a weight equivalent to $6.5 \mathrm{~kg}$ of air-dried soil was placed in a pot. The water content of the soil in each pot was maintained at the field capacity by adding water as required. The pots were labeled according to their respective treatments. The silicon in the form of SCB and zeolite were weighed to obtain the desired weight to apply for each treatment and then mixed into the soil until a homogenous mixture was obtained. The soil mixture was incubated for 1 week before planting. $\mathrm{KCl}$ was applied by mixing the soil with $\mathrm{KCL}$ in accordance with the respective treatment amounts homogeneously, 1 day before planting. Before sowing, bok choy seeds were soaked in water containing Bio-P 60 for 1 hour and then germinated using tray-based tissue. The seeds were germinated for 2 days and then transferred to the nursery tray. The seeds grew in the nursery tray for 7 days before being transplanted to the pots. The variables observed were plant height, number of leaves, leaf area, fresh shoot weight, dry shoot weight, fresh root weight, dry root weight, fresh plant weight, and dry plant weight. Plant height was measured from the base of the rootstock to the highest leaf tip before harvesting (60 days after planting). The number of leaves was determined by counting the number of leaves growing on the plant. Leaf area was calculated after harvest using the gravimetric method. Three leaves were taken from among the shortest leaf, medium-sized, and the longest leaves, their areas were calculated using the gravimetric method, and the result was then averaged. Leaf area was calculated as the number of leaves multiplied by the average leaf area. Fresh shoot weight was measured after harvesting, by picking and weighing the newly-harvested bok choy. Plant shoot weight measurements were made by drying shoots in an oven at a temperature of $70^{\circ} \mathrm{C}$ for 23 days until the weight, expressed in grams (g), was constant. 
Table 1. Selected characteristics of entisol soil

\begin{tabular}{|c|c|c|c|}
\hline Soil characteristics & Value & Soil characteristics & Value \\
\hline Soil texture & & Electrical conductivity $\left(\mathrm{dS} \mathrm{m}^{-1}\right)$ & 0.038 \\
\hline sand $(\%)$ & 61 & Salinity $\left(\mathrm{mg} \mathrm{L}^{-1}\right)$ & 19 \\
\hline silt (\%) & 11 & Exchangeable cations & \\
\hline clay (\%) & 28 & $\mathrm{Ca}^{2+}\left(\mathrm{cmol} \mathrm{kg}^{-1}\right)$ & 8.34 \\
\hline $\mathrm{pH}-\mathrm{H}_{2} \mathrm{O}(1: 5)$ & 6.3 & $\mathrm{Mg}^{2+}\left(\mathrm{cmol} \mathrm{kg}^{-1}\right)$ & 4.22 \\
\hline $\mathrm{pH}-\mathrm{KCl}(1: 5)$ & 6.2 & $\mathrm{~K}^{+}\left(\mathrm{cmol} \mathrm{kg}^{-1}\right)$ & 0.28 \\
\hline Organic-C (\%) & 0.38 & $\mathrm{Na}^{+}\left(\mathrm{cmol} \mathrm{kg}^{-1}\right)$ & 0.16 \\
\hline Total-N (\%) & 0.04 & $\mathrm{CEC}\left(\mathrm{cmol} \mathrm{kg}^{-1}\right)$ & 14.55 \\
\hline Total-P (\%) mg $\mathrm{P}_{2} \mathrm{O}_{5} 100 \mathrm{~g}^{-1}$ & 155 & Base saturation (\%) & 89 \\
\hline Total-K (\%) mg K ${ }_{2} \mathrm{O} 100 \mathrm{~g}^{-1}$ & 54 & $\mathrm{Si}(\%)$ & 0.17 \\
\hline P-Olsen (ppm) & 39.1 & Fe (\%) & 1.29 \\
\hline Available K (ppm) & 184 & $\mathrm{Al}(\%)$ & 0.68 \\
\hline
\end{tabular}

Table 2. Effect of silicon and salinity on agronomic performance of bok choy observed after 60 days of growth

\begin{tabular}{|c|c|c|c|c|c|c|c|c|c|}
\hline \multirow{3}{*}{ Treat. } & \multicolumn{9}{|c|}{ Observed Variables } \\
\hline & PH & NL & LA & FSW & DSW & FRW & DRW & FPW & DPW \\
\hline & $(\mathrm{cm})$ & (leaf plant $\left.^{-1}\right)$ & $\left(\mathrm{cm}^{2}\right)$ & \multicolumn{6}{|c|}{ 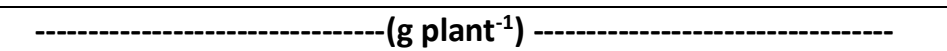 } \\
\hline \multicolumn{10}{|l|}{ Si Fertilizer } \\
\hline $\mathrm{S}_{0}$ & $18.05 \mathrm{~b}$ & $14.42 \mathrm{c}$ & $60.51 \mathrm{a}$ & $32.51 \mathrm{~b}$ & $3.04 \mathrm{a}$ & $2.81 \mathrm{a}$ & $0.74 \mathrm{a}$ & $35.32 \mathrm{~b}$ & $3.78 \mathrm{a}$ \\
\hline $\mathrm{S}_{1}$ & $19.62 \mathrm{ab}$ & $15.58 \mathrm{bc}$ & $64.22 \mathrm{a}$ & $46.42 \mathrm{a}$ & $3.33 \mathrm{a}$ & $3.41 \mathrm{a}$ & $1.05 \mathrm{a}$ & $49.84 a b$ & $4.30 \mathrm{a}$ \\
\hline $\mathrm{S}_{2}$ & $20.93 \mathrm{a}$ & $16.83 a b$ & $74.47 \mathrm{a}$ & $52.54 \mathrm{a}$ & $3.75 \mathrm{a}$ & $5.67 \mathrm{a}$ & $1.27 \mathrm{a}$ & $58.21 b$ & $5.02 \mathrm{a}$ \\
\hline $\mathrm{S}_{3}$ & $21.25 \mathrm{a}$ & $17.17 \mathrm{a}$ & $78.80 \mathrm{a}$ & $51.42 \mathrm{a}$ & $4.18 \mathrm{a}$ & $4.88 \mathrm{a}$ & $1.37 \mathrm{a}$ & $56.30 \mathrm{~b}$ & $5.55 a$ \\
\hline F cal & 3.84 & 4.75 & 1.55 & 3.81 & 1.7 & 2.13 & 1.2 & 4.08 & 1.75 \\
\hline \multicolumn{10}{|l|}{ Salinity } \\
\hline $\mathrm{K}_{0}$ & $20.73 \mathrm{a}$ & $16.25 \mathrm{a}$ & 73.09 & $50.20 \mathrm{a}$ & $3.65 \mathrm{a}$ & $3.75 \mathrm{a}$ & $1.04 \mathrm{a}$ & $53.95 \mathrm{a}$ & $4.68 \mathrm{a}$ \\
\hline $\mathrm{K}_{1}$ & 20.98 a & $16.71 \mathrm{a}$ & 68.91 & $50.44 \mathrm{a}$ & $3.7 \mathrm{a}$ & $3.81 \mathrm{a}$ & $1.02 \mathrm{a}$ & $54.25 \mathrm{a}$ & $4.72 \mathrm{a}$ \\
\hline $\mathrm{K}_{2}$ & $20.50 \mathrm{a}$ & 16.67 a & 78.32 & 47.91 a & $3.58 \mathrm{a}$ & $4.75 \mathrm{a}$ & $1.15 \mathrm{a}$ & $52.66 \mathrm{a}$ & $4.72 \mathrm{a}$ \\
\hline$K_{3}$ & $17.64 \mathrm{~b}$ & $14.38 \mathrm{~b}$ & 57.68 & $34.34 \mathrm{a}$ & $3.38 \mathrm{a}$ & $4.47 \mathrm{a}$ & $1.23 \mathrm{a}$ & $38.81 \mathrm{a}$ & $4.57 \mathrm{a}$ \\
\hline F cal & 4.41 & 3.66 & 1.63 & 2.65 & 0.13 & 0.3 & 0.10 & 2.10 & 0.15 \\
\hline
\end{tabular}

Note: $\mathrm{PH}=$ plant height, $\mathrm{NL}=$ number of leaves, $\mathrm{LA}=$ leaf area, $\mathrm{FSW}=$ fresh shoot weight, $\mathrm{DSW}=$ dry shoot weight, $\mathrm{FRW}=$ fresh root weight, $\mathrm{DRW}=$ dry root weight, $\mathrm{FPW}=$ fresh plant weight, $\mathrm{DW}=$ dry plant weight; $\mathrm{K}_{0}=$ salinity $0 \mathrm{dS}^{-1} ; \mathrm{K}_{1}=\mathrm{salinity}^{-1}$ $1 \mathrm{dS} \mathrm{m}^{-1} ; \mathrm{K}_{2}=2 \mathrm{dS} \mathrm{m}^{-1} ; \mathrm{K}_{3}=$ and $3 \mathrm{dS} \mathrm{m}^{-1} ; \mathrm{S}_{0}=0 \mathrm{~g} \mathrm{Si} \mathrm{pot}^{-1} ; \mathrm{S}_{1}=5 \mathrm{~g} \mathrm{Si} \mathrm{pot}^{-1} ; \mathrm{S}_{2}=10 \mathrm{~g} \mathrm{Si} \mathrm{pot}^{-1} ; \mathrm{S}_{3}=15 \mathrm{~g} \mathrm{Si} \mathrm{pot}^{-1}$

The data collected were analyzed for diversity using the $\mathrm{F}$ test at a $95 \%$ confidence level. If the $F$ test shows significantly different, a further test is performed using the Duncan test (Duncan's Multiple Range Test, DMRT).

\section{Results}

\subsection{The effects of silicon fertilizer on the agronomic characteristics of bok choy}

The provision of silicon from natural zeolite and SCB improved some aspects of the agronomic performance of bok choy, as represented by characteristics such as the plant height, the number of leaves, the fresh shoot weight, and the fresh plant weight of bok choy (Table 2). However, other agronomic characteristics did not improve significantly, such as dry shoot weight, fresh root weight, dry root weight, and dry plant weight.

The improvements in the agronomic components of plant height, number of leaves, fresh shoot weight, and fresh plant weight were 17.76, \%, $19.07 \%, 61.61 \%$, and $64.81 \%$, respectively (Table 3 ). The best dosage for improving both plant height and the number of leaves was $15 \mathrm{~g} \mathrm{Si} \mathrm{pot}^{-1}\left(\mathrm{~S}_{3}\right)$, while the best dosage for fresh shoot weight and fresh plant weight of bok choy was $10 \mathrm{~g} \mathrm{Si} \mathrm{pot}^{-1}\left(\mathrm{~S}_{2}\right)$.
The provision of silicon fertilizer did not significantly affect the agronomic performance of leaf area, dry shoot weight, fresh root weight, dry root weight, or dry plant weight although these characteristics did see an improvement compared to the control. The highest improvements for each component were $78.80 \%, 35 \%, 101.78 \%, 85.14 \%$, and 46.83 $\%$ for dry shoot weight, fresh root weight, dry root weight, and dry plant weight respectively (Table 3). The best dosage for leaf area, dry shoot weight, dry root weight, and dry plant weight of bok choy was $15 \mathrm{~g} \mathrm{Si} \mathrm{pot}^{-1}$ (S3), while the best dosage for fresh root weight of bok choy was $10 \mathrm{~g} \mathrm{Si} \mathrm{pot}^{-1}(\mathrm{~S} 2)$.

\subsection{The effects of salinity stress on the agronomic performance of bok choy}

The addition of soil salinity decreased the plant height and number of leaves, with the greatest reductions in plant height and number of leaves of $14.91 \%$ and $11.51 \%$, respectively, found at the dosage of $\mathrm{K} 3\left(3 \mathrm{dS} \mathrm{m}{ }^{-1}\right)$ (Table 3). The addition of salinity did not significantly affect leaf area, fresh shoot weight, dry shoot weight, fresh plant weight, dry fresh plant weight, fresh root weight, or dry root weight. However, it tended to decrease the characteristics of agronomic performance compared to the control. 
Table 3. Effect of silicon and salinity in the percentage of improvement and reduction of agronomic performance of bok choy observed after 60 days of growth

\begin{tabular}{|c|c|c|c|c|c|c|c|c|c|}
\hline \multirow{3}{*}{ Treat. } & \multicolumn{9}{|c|}{ Observed Variables } \\
\hline & PH & NL & LA & FSW & DSW & FRW & DRW & FPW & DPW \\
\hline & $(\mathrm{cm})$ & (leaf plant $^{-1}$ ) & $\left(\mathrm{cm}^{2}\right)$ & |------------ & - & (g p & $\left.t^{-1}\right)$ & -------'- & -.--- \\
\hline \multicolumn{10}{|c|}{ Si Fertilizer } \\
\hline SO & $0.00 \%$ & $0.00 \%$ & $0.00 \%$ & $0.00 \%$ & $0.00 \%$ & $0.00 \%$ & $0.00 \%$ & $0.00 \%$ & $0.00 \%$ \\
\hline S1 & $8.70 \%$ & $8.04 \%$ & $6.13 \%$ & $42.79 \%$ & $9.54 \%$ & $21.35 \%$ & $41.89 \%$ & $41.11 \%$ & $13.76 \%$ \\
\hline S2 & $15.96 \%$ & $16.71 \%$ & $74.47 \%$ & $61.61 \%$ & $23.36 \%$ & $101.78 \%$ & $71.62 \%$ & $64.81 \%$ & $32.80 \%$ \\
\hline S3 & $17.76 \%$ & $19.07 \%$ & $78.80 \%$ & $58.17 \%$ & $37.50 \%$ & $73.67 \%$ & $85.14 \%$ & $59.40 \%$ & $46.83 \%$ \\
\hline \multicolumn{10}{|l|}{ Salinity } \\
\hline KO & $0.00 \%$ & $0.00 \%$ & $0.00 \%$ & $0.00 \%$ & $0.00 \%$ & $0.00 \%$ & $0.00 \%$ & $0.00 \%$ & $0.00 \%$ \\
\hline K1 & $1.21 \%$ & $2.83 \%$ & $-5.72 \%$ & $0.48 \%$ & $1.37 \%$ & $1.60 \%$ & $-1.92 \%$ & $0.56 \%$ & $0.85 \%$ \\
\hline $\mathrm{K} 2$ & $-1.11 \%$ & $2.58 \%$ & $7.16 \%$ & $-4.56 \%$ & $-1.92 \%$ & $26.67 \%$ & $10.58 \%$ & $-2.39 \%$ & $0.85 \%$ \\
\hline K3 & $-14.91 \%$ & $-11.51 \%$ & $-21.08 \%$ & $-31.59 \%$ & $-7.40 \%$ & $19.20 \%$ & $18.27 \%$ & $28.06 \%$ & $-2.35 \%$ \\
\hline
\end{tabular}

Note: $\mathrm{PH}=$ plant height, $\mathrm{NL}=$ number of leaves, $\mathrm{LA}=$ leaf area, $\mathrm{FSW}=$ fresh shoot weight, $\mathrm{DSW}=$ dry shoot weight, $\mathrm{FRW}=$ fresh root weight, $\mathrm{DRW}=$ dry root weight, $\mathrm{FPW}=$ fresh plant weight, $\mathrm{DW}=$ dry plant weight; $\mathrm{K}_{0}=$ salinity $0 \mathrm{dS} \mathrm{m}^{-1} ; \mathrm{K}_{1}=$ salinity $1 \mathrm{dS} \mathrm{m}^{-1} ; \mathrm{K}_{2}=2 \mathrm{dS} \mathrm{\textrm {m } ^ { - 1 }}$; $\mathrm{K}_{3}=$ and $3 \mathrm{dS} \mathrm{m} \mathrm{m}^{-1} ; \mathrm{S}_{0}=0 \mathrm{~g} \mathrm{Si} \mathrm{pot}{ }^{-1} ; \mathrm{S}_{1}=5 \mathrm{~g} \mathrm{Si} \mathrm{pot}^{-1} ; \mathrm{S}_{2}=10 \mathrm{~g} \mathrm{Si} \mathrm{pot}^{-1} ; \mathrm{S}_{3}=15 \mathrm{~g} \mathrm{Si} \mathrm{pot}^{-1}$

Table 4. Interaction of silicon and salinity on plant height $(\mathrm{cm})$ of bok choy observed after 60 days of growth

\begin{tabular}{ccccl}
\hline Salinity & $\mathbf{S}_{\mathbf{0}}$ & $\mathbf{S}_{\mathbf{1}}$ & $\mathbf{S}_{\mathbf{2}}$ & \multicolumn{1}{c}{$\mathbf{S}_{\mathbf{3}}$} \\
\hline $\mathrm{K}_{0}$ & $19.3 \mathrm{ba}$ & $21.7 \mathrm{aa}$ & $20.0 \mathrm{bb}$ & $21.9 \mathrm{aa}$ \\
$\mathrm{K}_{1}$ & $19.5 \mathrm{ca}$ & $19.9 \mathrm{cb}$ & $23.4 \mathrm{aa}$ & $21.1 \mathrm{ba}$ \\
$\mathrm{K}_{2}$ & $20.2 \mathrm{ba}$ & $20.1 \mathrm{bb}$ & $20.3 \mathrm{bb}$ & $21.4 \mathrm{aab}$ \\
$\mathrm{K}_{3}$ & $13.2 \mathrm{cb}$ & $16.7 \mathrm{bc}$ & $20.0 \mathrm{ab}$ & $20.6 \mathrm{ab}$ \\
\hline
\end{tabular}

Note: Means followed by the same capital letter in the rows and the same small letter in the columns do not differ by DMRT at $\mathrm{P}<0.05$. $\mathrm{S}=$ silicon treatment; $\mathrm{K}=$ salinity treatment; $\mathrm{KO}=$ salinity $0 \mathrm{dS} \mathrm{m}-1$; $\mathrm{K} 1=$ salinity $1 \mathrm{dS} \mathrm{m}-1 ; \mathrm{K} 2=2 \mathrm{dS} \mathrm{m}-1 ; \mathrm{K} 3=$ and $3 \mathrm{dS} \mathrm{m}-1 ; \mathrm{S} 0=0 \mathrm{~g}$ Si pot-1; S1= $5 \mathrm{~g}$ Si pot-1; S2=10 g Si pot-1; S3= 15 g Si pot-1

Table 5. Interaction of silicon and salinity effects on the number of leaves of bok choy observed after 60 days growth

\begin{tabular}{ccccc}
\hline Salinity & $\mathbf{S}_{\mathbf{0}}$ & $\mathbf{S}_{\mathbf{1}}$ & $\mathbf{S}_{\mathbf{2}}$ & $\mathbf{S}_{\mathbf{3}}$ \\
\hline $\mathrm{K}_{0}$ & $13.8 \mathrm{dc}$ & $17.0 \mathrm{ba}$ & $16.2 \mathrm{cb}$ & $18.0 \mathrm{aa}$ \\
$\mathrm{K}_{1}$ & $16.0 \mathrm{ca}$ & $15.7 \mathrm{cb}$ & $18.3 \mathrm{aa}$ & $16.8 \mathrm{bb}$ \\
$\mathrm{K}_{2}$ & $16.3 \mathrm{ca}$ & $15.8 \mathrm{cb}$ & $16.7 \mathrm{bb}$ & $17.8 \mathrm{aa}$ \\
$\mathrm{K}_{3}$ & $11.5 \mathrm{cb}$ & $13.8 \mathrm{bc}$ & $16.2 \mathrm{ab}$ & $16.0 \mathrm{ac}$ \\
\hline
\end{tabular}

Note: Means followed by the same capital letter in the rows and the same small letter in the columns do not differ by $\mathrm{DMRT}$ at $\mathrm{P}<0.05 . \mathrm{S}=$ silicon treatment; $\mathrm{K}=$ salinity treatment; $\mathrm{K}_{0}=$ salinity $0 \mathrm{dS} \mathrm{m}^{-1} ; \mathrm{K}_{1}=$ salinity $1 \mathrm{dS} \mathrm{m}^{-1}$; $\mathrm{K}_{2}=2 \mathrm{dS} \mathrm{m}^{-1} ; \mathrm{K}_{3}=$ and $3 \mathrm{dS} \mathrm{m}^{-1} ; \mathrm{S}_{0}=0 \mathrm{~g} \mathrm{Si} \mathrm{pot}^{-1} ; \mathrm{S}_{1}=5 \mathrm{~g}$ Si pot ${ }^{-1} ; S_{2}=10 \mathrm{~g} \mathrm{Si} \mathrm{pot}^{-1} ; S_{3}=15 \mathrm{~g} \mathrm{Si} \mathrm{pot}^{-1}$

The largest percentages by which these components were reduced were $21.08 \%, 31.59 \%, 7.40 \%, 26.67 \%, 2.35 \%$, $26.67 \%$, and $18.27 \%$ for leaf area, fresh shoot weight, dry shoot weight, fresh plant weight, dry plant weight, fresh root weight, and dry root weight respectively (Table 3 ).
Table 6. Interaction of silicon and salinity on the leaf area $\left(\mathrm{cm}^{2}\right)$ of bok choy observed after 60 days of growth

\begin{tabular}{ccccc}
\hline Salinity & $\mathbf{S}_{\mathbf{0}}$ & $\mathbf{S}_{\mathbf{1}}$ & $\mathbf{S}_{\mathbf{2}}$ & $\mathbf{S}_{\mathbf{3}}$ \\
\hline $\mathrm{K}_{0}$ & $66.8 \mathrm{ca}$ & $76.6 \mathrm{ba}$ & $63.5 \mathrm{cc}$ & $85.5 \mathrm{aa}$ \\
$\mathrm{K}_{1}$ & $63.1 \mathrm{ba}$ & $67.4 \mathrm{bb}$ & $79.9 \mathrm{ab}$ & $65.2 \mathrm{bc}$ \\
$\mathrm{K}_{2}$ & $66.7 \mathrm{ba}$ & $68.2 \mathrm{de}$ & $88.3 \mathrm{aa}$ & $90.1 \mathrm{aa}$ \\
$\mathrm{K}_{3}$ & $45.5 \mathrm{cb}$ & $44.7 \mathrm{cc}$ & $66.1 \mathrm{bc}$ & $74.4 \mathrm{ab}$ \\
\hline
\end{tabular}

Note: Means followed by the same capital letter in the rows and the same small letter in the columns do not differ by DMRT at $\mathrm{P}<0.05 . \mathrm{S}=$ silicon treatment; $\mathrm{K}=$ salinity treatment; $\mathrm{K}_{0}=$ salinity $0 \mathrm{dS} \mathrm{m}^{-1} ; \mathrm{K}_{1}=$ salinity $1 \mathrm{dS} \mathrm{m}^{-1}$; $\mathrm{K}_{2}=2 \mathrm{dS} \mathrm{m}^{-1} ; \mathrm{K}_{3}=$ and $3 \mathrm{dS} \mathrm{m}{ }^{-1} ; \mathrm{S}_{0}=0 \mathrm{~g} \mathrm{Si} \mathrm{pot}^{-1} ; \mathrm{S}_{1}=5 \mathrm{~g}$ Si pot ${ }^{-1} ; S_{2}=10 \mathrm{~g} \mathrm{Si} \mathrm{pot}^{-1} ; S_{3}=15 \mathrm{~g} \mathrm{Si} \mathrm{pot}^{-1}$

Table 7. Interaction of silicon and salinity on fresh plant weight (g) of bok choy observed after 60 days of growth

\begin{tabular}{ccccc}
\hline Salinity & $\mathbf{S}_{\mathbf{0}}$ & $\mathbf{S}_{\mathbf{1}}$ & $\mathbf{S}_{\mathbf{2}}$ & $\mathbf{S}_{\mathbf{3}}$ \\
\hline $\mathrm{K}_{0}$ & 33.96 & 56.55 & 56.44 & 53.81 \\
$\mathrm{~K}_{1}$ & 42.17 & 50.06 & 61.86 & 47.66 \\
$\mathrm{~K}_{2}$ & 37.98 & 49.31 & 49.26 & 55.07 \\
$\mathrm{~K}_{3}$ & 15.90 & 29.75 & 42.59 & 49.11 \\
\hline
\end{tabular}

Note: Means followed by the same capital letter in the rows and the same small letter in the columns do not differ by $\mathrm{DMRT} P<0.05 . \mathrm{S}=$ silicon treatment; $\mathrm{K}=$ salinity treatment; $\mathrm{K}_{0}=$ salinity $0 \mathrm{dS} \mathrm{m}^{-1} ; \mathrm{K}_{1}=$ salinity $1 \mathrm{dS} \mathrm{m}^{-1}$; $\mathrm{K}_{2}=2 \mathrm{dS} \mathrm{m}^{-1} ; \mathrm{K}_{3}=$ and $3 \mathrm{dS} \mathrm{m}^{-1} ; \mathrm{S}_{0}=0 \mathrm{~g} \mathrm{Si} \mathrm{pot}^{-1} ; \mathrm{S}_{1}=5 \mathrm{~g}$ Si pot ${ }^{-1} ; S_{2}=10 \mathrm{~g} \mathrm{Si} \mathrm{pot}^{-1} ; \mathrm{S}_{3}=15 \mathrm{~g} \mathrm{Si} \mathrm{pot}^{-1}$

\subsection{The effects of silicon fertilizer on the agronomic characteristics of bok choy under salinity stress conditions}

The experimental results showed that the interaction between the silicon fertilizer and salinity stress affected some agronomic performance characteristics of bok choy: plant height, number of leaves, and leaf area (Table 4, Table 5, and Table 6). The other variables showed no significant 
interaction between the application of silicon fertilizer and salinity stress.

Table 8. Interaction of silicon and salinity on dry plant weight (g) of bok choy observed after 60 days of growth

\begin{tabular}{lcccc}
\hline Salinity & $\mathbf{S}_{\mathbf{0}}$ & $\boldsymbol{S}_{\mathbf{1}}$ & $\boldsymbol{S}_{\mathbf{2}}$ & $\boldsymbol{S}_{\mathbf{3}}$ \\
\hline $\mathrm{K}_{0}$ & 3.28 & 3.83 & 3.66 & 3.81 \\
$\mathrm{~K}_{1}$ & 2.98 & 3.65 & 3.83 & 4.30 \\
$\mathrm{~K}_{2}$ & 3.07 & 3.83 & 3.41 & 3.97 \\
$\mathrm{~K}_{3}$ & 2.81 & 1.99 & 4.08 & 4.64 \\
\hline
\end{tabular}

Note: Means followed by the same capital letter in the rows and the same small letter in the columns do not differ by DMRT at $\mathrm{P}<0.05 . \mathrm{S}=$ silicon treatment; $\mathrm{K}=$ salinity treatment; $\mathrm{K}_{0}=$ salinity $0 \mathrm{dS} \mathrm{m}^{-1} ; \mathrm{K}_{1}=$ salinity $1 \mathrm{dS} \mathrm{m}^{-1}$; $\mathrm{K}_{2}=2 \mathrm{dS} \mathrm{m}^{-1} ; \mathrm{K}_{3}=$ and $3 \mathrm{dS} \mathrm{m}^{-1} ; \mathrm{S}_{0}=0 \mathrm{~g} \mathrm{Si} \mathrm{pot}^{-1} ; \mathrm{S}_{1}=5 \mathrm{~g}$ Si pot ${ }^{-1} ; S_{2}=10 \mathrm{~g} \mathrm{Si} \mathrm{pot}^{-1} ; \mathrm{S}_{3}=15 \mathrm{~g} \mathrm{Si} \mathrm{pot}^{-1}$

\section{Discussion}

The capabilities of silicon fertilizer to improve fresh plant weight and dry plant weight at each level of salinity stress are presented in Table 7 and Table 8. The application of silicon significantly improved some agronomic performance characteristics of bok choy under salinity stress conditions, i.e., plant height, number of leaves, and leaf area (Table 3, Table 4, and Table 5). This showed that silicon can alleviate the negative effects of salinity stress on the growth of bok choy. The improvements in the number of leaves and leaf area enabled the plant to get more energy from sunlight and improve the process of photosynthesis to support the growth of plants under salinity stress conditions. These results are in line with findings by Liu et al., (2019) showing that the provision of silicon can alleviate salt stress in several plants, involving various regulatory mechanisms such as photosynthesis, detoxification of harmful reactive oxygen species using antioxidants, and non-antioxidants, and proper nutrient management. Similar results from Hussein \& AbouBaker (2014) and Hussein et al., (2012) have shown that silicon has the ability to improve the growth performance of plants under conditions of salinity stress. This is consistent with the finding by Soundararajan et al. (2017) that silicon increased the abundance of photosynthesis and energy metabolism-related proteins in $R$. hybrida under salt stress. It is also supported by the finding by Muneer et al. (2014) that silicon application to tomatoes under salinity stress conditions increased total chlorophyll and carotenoid content, net photosynthesis rate, stomatal conductance, and transpiration, and alleviated the reduction in cytochrome $b 6 / f$ and the ATP-synthase complex. The products of photosynthesis are distributed to all parts of the plant so that the agronomic performance of the plant increases. Putri et al. (2017) found that photosynthates in vegetative plants are distributed to and stored in roots, stems, and leaves for storage of food reserves, thus affecting the wet weight and dry weight of the plant. The improvement in the physiological process is also represented by the increases in fresh weight and dry weight of bok choy. In addition, the application of silicon was also able to alleviate the salinity stress on fresh plant weight and dry plant weight. As shown in Table 7 and Table 8 , the availability of silicon at each level of salinity $\left(\mathrm{K}_{0}\right.$,
$K_{1}, K_{2}$, and $K_{3}$ ) improved the fresh weight and fresh plant weight. This is similar to the results of some previous studies which showed that the provision of silicon to the saline soil could alleviate the negative effect of salinity stress on processes such as root growth and shoot growth (Zare et al., 2015). The improvement in fresh weight and dry weight of plants was due to improvements in the physiological processes in the plants, which in turn improved the availability of other nutrients (Nascimento et al., 2018). This is supported by the finding of Azizi et al. (2016) that the application of silicon prevented $\mathrm{Na}^{+}$accumulation and enhanced $\mathrm{K}^{+}$content in Medicago scutellata plants. The improvement of nutrient absorption was presumably due to the improvement in the root system so that the absorption of nutrients by the bok choy was more effective. Table 2 shows that the fresh weight of the roots significantly increased.

The improvement due to silicon application makes for a better root system that can absorb nutrients effectively (Amrullah et al., 2014; Putri et al., 2017). The higher occurrence of root hairs improves the capability of plants for the uptake of water and helps to alleviate stresses due to salinity, drought, and heavy metals (Singh et al., 2012). The findings of Soundararajan et al. (2018) on the application of silicon to $R$. hybrida also showed that silicon application in salt-stressed plants resulted in maintenance of the structural integrity of the root cell wall of the plant.

The provision of silicon increased the agronomic performance of bok choy grown on the coastal Entisols in such aspects as the dry shoot weight, fresh root weight, dry root weight, and dry plant weight (Table 2 ). This showed that Si has the capability to improve the physiological processes in the bok choy plant, including photosynthesis. The availability of silicon in entisols and Cation Exchange Capacity (CEC) is very low (Table 1), such that the provision of silicon fertilizer to entisols was able to improve some agronomic performance. According to Prasetyo et al. (2010), one of the roles of silicon is to increase photosynthetic efficiency so that the plant's production increases. Silicon accumulates with lignin in cell walls, increasing the dry weight of the canopy (Gerami et al., 2012). Silicon also increases the rate of photosynthesis and prevents chlorophyll damage, allowing the production of more photosynthates, which are able to increase the dry weight of the plant (Epstein, 2009). The improvements in the agronomic components of bok choy varied: the lowest improvement percentage was $17.76 \%$ (plant height) and the highest improvement percentage was $101.78 \%$ (fresh root weight) at a dosage of $15 \mathrm{~g} \mathrm{Si} \mathrm{pot}^{-1}$ (Table 3). The improvement in fresh plant weight (production of bok choy) was $64.18 \%$ with a dosage of $10 \mathrm{~g} \mathrm{pot}^{-1}$ (Table 3) compared to the control, presumably due to the variation in the distribution of photosynthesis products to the specific organs of the plant in accordance with the distribution of silicon in the plant organs. Ning et al. (2014) found that the application of silicon fertilizer significantly improved the concentration of silicon in the leaves, stems, and grains of rice plants and that the concentration of silicon is different among the organs of the plant, in the order leaf>stem>grain.

\section{Conclusion}


The provision of silicon from natural zeolite and SCB improved some aspects of agronomic performance such as plant height, number of leaves, fresh shoot weight, and fresh plant weight of bok choy, but it did not significantly affect the agronomic performance of dry shoot weight, fresh root weight, dry root weight, and dry plant weight. Increasing soil salinity by up to $3 \mathrm{dS} \mathrm{m}^{-1}$ of soil decreased the plant height and number of leaves, but did not significantly affect fresh shoot weight, dry shoot weight, fresh plant weight, dry plant weight, fresh root weight, and dry root weight. However, increasing salinity resulted in plants with agronomic performance lower than the control. The provision of silicon fertilizer from zeolite and SCB compost improved plant height, number of leaves, leaf area, fresh plant weight, and dry plant weight of bok choy plants under conditions of salinity stress in entisol soil. The fresh plant weight (production of bok choy) with a dose of $10 \mathrm{~g} \mathrm{pot}^{-1}$ improved by $64.18 \%$ compared to the control.

\section{Declaration of Competing Interest}

The authors declare no competing financial or personal interests that may appear and influence the work reported in this paper.

\section{References}

Ahmed, M., Qadeer, U., \& Aslam, M. A. (2011). Silicon application and drought tolerance mechanism of sorghum. African Journal of Agricultural Research, 6(3), 594-607.

Amrullah, Sopandie, D., Sugianta, \& Junaedi, A. (2014). Peningkatan produktivitas tanaman padi (Oryza sativa L.) melalui pemberian nano silika. Jurnal Pangan, 23(1), 17-32.

Auliani, P. A. (2013). Panjang Garis Pantai Indonesia Capai $99.000 \quad$ Kilometer. Accessed from https://Nationalgeographic. Grid. Id/Read/13285616/Terbaru-Panjang-Garis-PantaiIndonesia-Capai-99000-Kilometer.

Ayers, R. S., \& Westcot, D. W. (1985). Water quality for agriculture. FAO.

Azizi, M., Abdolzadeh, A., Mehrabanjoubani, P., \& Sadeghipour, H. R. (2016). Evaluation of effect of silicon on $\mathrm{NaCl}$ tolerance in annual Medicago scutellata L. Iranian Journal of Field Crops Research, 14(1).

Camargo, M. S. de, Rocha, G., \& Korndörfer, G. H. (2013). Silicate fertilization of tropical soils: silicon availability and recovery index of sugarcane. Revista Brasileira de Ciência Do Solo, 37(5), 1267-1275.

Deinlein, U., Stephan, A. B., Horie, T., Luo, W., Xu, G., \& Schroeder, J. I. (2014). Plant salt-tolerance mechanisms. Trends in Plant Science, 19(6), 371-379.

Epstein, E. (2009). Silicon: its manifold roles in plants. Annals of Applied Biology, 155(2), 155-160.

Farooq, M. A., Saqib, Z. A., Akhtar, J., Bakhat, H. F., Pasala, R.K., \& Dietz, K.-J. (2019). Protective role of silicon (Si) against combined stress of salinity and boron (B) toxicity by improving antioxidant enzymes activity in rice. Silicon, 11(4), 2193-2197.
Gerami, M., Fallah, A., \& Moghadam, M. R. K. (2012). Study of potassium and sodium silicate on the morphological and chlorophyll content on the rice plant in pot experiment (Oryza Sativa L.). International Journal of Agriculture and Crop Sciences (IJACS), 4(10), 658-661.

Ghassemi-Golezani, K., \& Lotfi, R. (2015). The impact of salicylic acid and silicon on chlorophyll a fluorescence in mung bean under salt stress. Russian Journal of Plant Physiology, 62(5), 611-616.

Hanafy Ahmed, A. H., Harb, E. M., Higazy, M. A., \& Morgan, S. H. (2008). Effect of silicon and boron foliar applications on wheat plants grown under saline soil conditions. International Journal of Agricultural Research, 3(1), 126.

Hasanuzzaman, M., Nahar, K., \& Fujita, M. (2013). Plant response to salt stress and role of exogenous protectants to mitigate salt-induced damages. In Ecophysiology and responses of plants under salt stress (pp. 25-87). Springer.

Husnaeni, F., \& Setiawati, M. R. (2018). Pengaruh Pupuk Hayati dan Anorganik Terhadap Populasi Azotobacter, Kandungan N, dan Hasil Pakcoy Pada Sistem Nutrient Film Technique. Jurnal Biodjati, 3(1), 90-98.

Hussein, M. M., \& Abou-Baker, N. H. (2014). Growth and mineral status of moringa plants as affected by silicate and salicylic acid under salt stress. Int J Plants Soil Sci, 3, 63-177.

Hussein, M. M., Mehanna, H., \& Abou-Baker, N. H. (2012). Growth, photosynthetic pigments, and mineral status of cotton plants as affected by salicylic acid and salt stress. Journal of Applied Sciences Research, November, 5476-5484.

Kertonegoro, B. D. (2001). Gumuk pasir pantai di DI Yogyakarta: Potensi dan pemanfaatannya untuk pertanian berkelanjutan. Prosiding Seminar Nasional Pemanfaatan Sumberdaya Lokal Untuk Pembangunan Pertanian Berkelanjutan. Universitas Wangsa Manggala Pada Tanggal, 2, 46-54.

Liu, B., Soundararajan, P., \& Manivannan, A. (2019). Mechanisms of silicon-mediated amelioration of salt stress in plants. Plants, 8(9), 307.

Ma, J. F., \& Takahashi, E. (2002). Soil, fertilizer, and plant silicon research in Japan. Elsevier.

Makoi, J. H. J. R., \& Verplancke, H. (2010). Effect of gypsum placement on the physical-chemical properties of a saline sandy loam soil. Australian Journal of Crop Science, 4(7), 556.

Mindari, W. (2009). Cekaman Garam dan Dampaknya Pada Kesuburan Tanah dan Pertumbuhan tanaman. Undergraduate Thesis, UPN" Veteran" Jawa Timur, Surabaya.

Muneer, S., Park, Y. G., Manivannan, A., Soundararajan, P., \& Jeong, B. R. (2014). Physiological and proteomic analysis in chloroplasts of Solanum Lycopersicum L. under silicon efficiency and salinity stress. International Journal of Molecular Sciences, 15(12), 21803-21824.

Nascimento, I. D. O., Rodrigues, A. A. C., Braun, H., Santos, C. C., \& Catarino, A. D. M. (2018). Silicon fertilization and seed microbiolization on disease severity and 
agronomic performance of upland rice. Revista Caatinga, 31(1), 126-134. https://doi.org/10.1590/1983-21252018v31n115rc

Ning, D., Song, A., Fan, F., Li, Z., \& Liang, Y. (2014). Effects of slag-based silicon fertilizer on rice growth and brownspot resistance. Plos One, 9(7), e102681.

Oliveira, J. R. de, Koetz, M., Bonfim-Silva, E. M., \& da Silva, T. J. A. (2016). Silicon fertilization and soil water tensions on rice development and yield. Revista Brasileira de Engenharia Agrícola e Ambiental, 20(2), 138-143.

Prasetyo, T. B., Yasin, S., \& Yeni, E. (2010). Pengaruh pemberian abu batubara sebagai sumber silika (Si) Bagi pertumbuhan dan produksi tanaman padi (Oryza sativa L). Jurnal Solum, 7(1), 1-6.

Putri, F. M., Suedy, S. W. A., \& Darmanti, S. (2017). The effects of nano-silica fertilizer on the number of stomata, chlorophyll content, and growth of black rice (Oryza sativa L. CV. Japonica)". Available online at: http://www.ejournal.undip.ac.id/indek.php/baf/index.

Sabaghnia, N., \& Janmohammadi, M. (2015). Effect of nanosilicon particles application on salinity tolerance in early growth of some lentil genotypes/Wpływ nanocząstek krzemionki na tolerancję zasolenia we wczesnym rozwoju niektórych genotypów soczewicy. Annales UMCS, Biologia, 69(2), 39-55.

Shahzad, M., Witzel, K., Zörb, C., \& Mühling, K. H. (2012). Growth-related changes in subcellular ion patterns in maize leaves (Zea mays L.) under salt stress. Journal of Agronomy and Crop Science, 198(1), 46-56.

Singh, A. K., Kumar, R., Pareek, A., Sopory, S. K., \& SinglaPareek, S. L. (2012). Overexpression of rice CBS domain containing protein improves salinity, oxidative, and heavy metal tolerance in transgenic tobacco. Molecular Biotechnology, 52(3), 205-216.
Sipayung, R. (2003). Stres garam dan mekanisme toleransi tanaman. Undergraduate Thesis, USU Digital Library.

Soundararajan, P., Manivannan, A., Ko, C. H., \& Jeong, B. R. (2018). Silicon enhanced redox homeostasis and protein expression to mitigate the salinity stress in Rosa hybrida 'Rock Fire.' Journal of Plant Growth Regulation, 37(1), 16-34.

Soundararajan, P., Manivannan, A., Ko, C. H., Muneer, S., \& Jeong, B. R. (2017). Leaf physiological and proteomic analysis to elucidate silicon induced adaptive response under salt stress in Rosa hybrida 'Rock Fire.' International Journal of Molecular Sciences, 18(8), 1768.

Tantawy, A. S., Salama, Y. A. M., El-Nemr, M. A., \& AbdelMawgoud, A. M. R. (2015). Nano silicon application improves salinity tolerance of sweet pepper plants. International Journal of ChemTech Research, 8(10), 11-17.

Usfiani, Budiyanto, G., \& Mulyono. (2016). Pemanfaatan arang ampas tebu -azolla pada cabai keriting merah di lahan berpasir pantai, Samas, Bantul.

Yin, L., Wang, S., Tanaka, K., Fujihara, S., Itai, A., Den, X., \& Zhang, S. (2016). Silicon-mediated changes in polyamines participate in silicon-induced salt tolerance in Sorghum bicolor L. Plant, Cell \& Environment, 39(2), 245-258.

Yustinah. (2013). Keseimbangan absorpsi asam lemak bebas dan perosida di dalam minyak kelapa sawit mentah (CPO) menggunakan bioadsorben dari ampas tebu. Jurnal Konversi, 02(2), 59-67.

Zare, H. R., Ghanbarzadeh, Z., Behdad, A., \& Mohsenzadeh, S. (2015). Effect of silicon and nano silicon on reduction of damage caused by salt stress in maize (Zea mays) seedlings. Iranian Journal Of Plant Biology, 7(26), 59-74. 